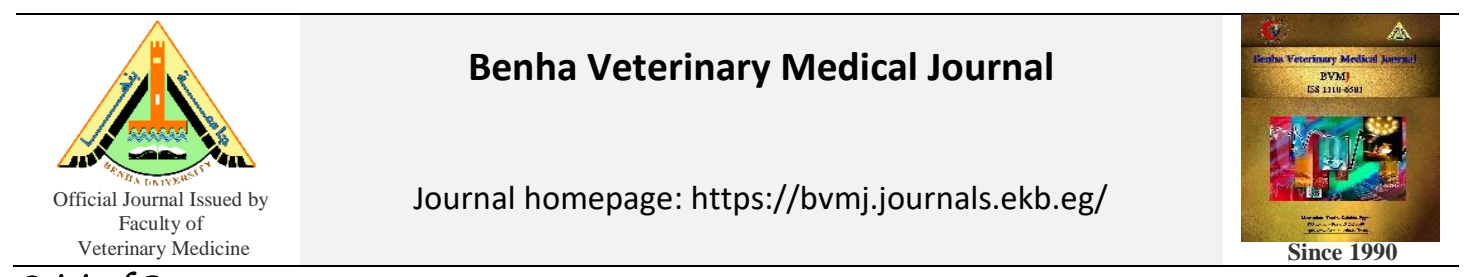

Original Paper

\title{
The effects of live yeast (Saccharomyces cerevisiae) and chitosan on digestion coefficient and molecular biology of main cellulolytic bacteria in male balady goat
}

\author{
Abd- Elkader, A. Y., Azab, M. E., Randa, S. Esmail, Abeer A. Nafeaa, Shousha, S. M.
}

Department of Physiology, Faculty of Veterinary Medicine, Benha University.

\begin{tabular}{|c|c|}
\hline ARTICLE INFO & ABSTRACT \\
\hline $\begin{array}{l}\text { Keywords } \\
\text { Balady goat } \\
\text { Cellulolytic bacteria } \\
\text { Chitosan } \\
\text { Digestion coefficient } \\
\text { Saccharomyces cerevisiae }\end{array}$ & $\begin{array}{l}\text { The present study throw lights on the influence of dietary supplementation of live dried yeast } \\
\text { Saccharomyces cerevisiae and chitozan on digestion coefficient and molecular biology of some } \\
\text { cellulolytic bacteria in male Balady goats. A total number of } 12 \text { castrated adult male Balady } \\
\text { goats aged one-year-old were allocated into three equal groups. Concentrates were offered at } \\
\text { rate of } 3 \% \text { of body weight. Experimental groups were control group fed on basal diet without } \\
\text { any feed additives, Saccharomyces cerevisiae group fed on basal diet with } S \text {. cerevisiae } \\
\text { additive at rate of } 0.3 \%(3 \mathrm{Kg} / \text { ton concentrate), and chitosan group fed on basal diet with } \\
\text { chitosan additive at rate of } 0.2 \% \text { ( } 2 \mathrm{~kg} / \text { ton concentrate). Results revealed significant increase } \\
(p<0.05) \text { in nutrient digestibility of dry matter, crude protein, ether extract (EE), crude fiber, } \\
\text { nitrogen free extract, and Ash. Moreover, there was a significant }(\mathrm{P}<0.05) \text { up regulation of } \\
\text { genes expression level in } S \text {. cerevisiae and chitosan groups when compared with the control } \\
\text { except in EE showed non-significant increase in chitosan group compared with the control } \\
\text { group. Thus, it is recommended to use } S \text {. cerevisiae to improve feed efficiency of diet, growth } \\
\text { and multiplication of ruminal microbes. }\end{array}$ \\
\hline
\end{tabular}

\section{INTRODUCTION}

Goat meat has gained market mainly due to increased demand for healthy foods because of its low-fat content. Goat play an important economic role and make a significant contribution to both domestic and export markets through provision of food (meat and milk) and non-food (manure, skin and wool) products (Polizel et al., 2016). Although goats play a significant role in national economy of the country to date the benefit obtained from these livestock are hampered by different constrains (Duguma et al., 2011). In recent years, there has been considerable interest in food safety implications of probiotics and prebiotics (Jacob and Nagaraja, 2012). Saccharomyces cerevisiae as probiotics have been extensively used in ruminants for improving performance and normalizing rumen fermentation (Chevaux and Fabre, 2007). In addition, yeast saccharomyces cerevisiae create better conditions for the growth of anaerobic cellulolytic bacteria by using the traces of available oxygen on the surfaces of freshly ingested feed and stimulate their attachment to cellulose particles. Yeasts can improve rumen bacterial growth and protein synthesis, bacterial enzymatic activities, digestion of fiber, voluntary feed intake and animal production (Roger et al., 1990; Jouany et al., 1999). Numerous studies documented positive effects of YC not only on the rumen environment, but also on the improvement of microbial activities (Chevaux and Fabre, 2007). Chitozan, a deacetylated chitin, is widespread in nature from the exoskeletons of arthropods such as crabs, shrimps, insects, and other marine creatures in the crustacean family are good sources of chitozan ( $\mathrm{Li}$ et al.,
2009). Chitozan has become a new candidate as a growthpromoter for farm animals. Chitozan can be used as an additive modulator of rumen fermentation because its capability to improve nutrient digestibility (Araújo et al., 2015; Mingoti et al., 2016). Therefore, the present study was undertaken to compare the impacts of feeding Saccharomyces cerevisiae on rumen fermentation functions and activity of fibrolytic bacteria in male balady goats.

\section{MATERIAL AND METHODS}

\section{1. Experimental design:}

A total number of 12 castrated healthy adult male Balady goats aged one year old and weighing $24 \pm 1 \mathrm{Kg}$ were obtained from a private farm for Balady goats' production in El-Kalioubia Governorate, Egypt during the period from the end of December 2017 till the end of April 2018 (4 months). The animals were allocated into three similar groups (4 males for each group) with a completely randomized design. Concentrates were offered at rate of $3 \%$ of live body weight. The feed additives used in this study included are (1) Saccharomyces cerevisiae (Brewer's yeast, Angle Yeast Co., Inc. assay) with $3 \times 10^{9} \mathrm{CFU} / \mathrm{gm}$ (2) Chitozan (Marine chemicals Co.) extracted from crab shells of medium molecular weight, deacetylation degree was $>85 \%$. The experimental groups were control group fed on basal diet without any feed additives, Saccharomyces cerevisiae group fed on basal diet with Saccharomyces cerevisiae additive at rate of $0.3 \%$ ( $3 \mathrm{Kg} /$ ton concentrate), and chitozan group fed on basal diet with chitozan additive at rate of $0.2 \%(2 \mathrm{~kg} / \mathrm{ton}$ concentrate). The animals were reared for 4 months as the

\footnotetext{
* Corresponding author: Abd- Elkader, A. Y., Department of Physiology, Faculty of Veterinary Medicine, Benha University.
} 
$1^{\text {st }}$ month for acclimatization of goats for new environmental conditions, the $2^{\text {nd }}$ month for adaptation of goats to feed additive substance and last two months for collection of the samples.

All animals were managed at the same environmental and nutritional conditions. The goats were housed in separated pens of the same size (one pen for each group) with special feeders and drinkers. The feed and the water were supplied ad libitum. The ratio between goats and feeder was 4:1. Goats were fed on concentrate feed mixture ration (its ingredients and its chemical analysis are illustrated in table 1) with about $14 \%$ crude protein. Samples of ruminal juice for expressions of selected bacterial DNA of Ruminococcus flavefaciens, Ruminococcus albus and Fibrobacter succinogenes genes collected at the beginning of the $3^{\text {rd }}$ month of experiment $\left(8^{\text {th }}\right.$ week) then continued every 2 weeks till the end of experiment (16 ${ }^{\text {th }}$ week). Fecal samples were collected three times at the beginning of the $3^{\text {rd }}$ month of experiment ( $8^{\text {th }}$ week $)$, beginning of the $4^{\text {th }}$ month $\left(12^{\text {th }}\right.$ week) and at the end of the $4^{\text {th }}$ month $\left(16^{\text {th }}\right.$ week $)$.

Table 1 The feed ingredients and chemical analysis of the ration for adult goats

\begin{tabular}{llll}
\hline Feed ingredients & $\%$ & $\begin{array}{l}\text { Chemical analysis (\%) of } \\
\text { the basal diet on dry matter } \\
\text { basis }\end{array}$ & $\%$ \\
\hline Yellow corn (8\%pt.) & $55 \%$ & Dry matter (DM) & 82.3 \\
Wheat bran. & $15.8 \%$ & Crude protein (CP) & 14.05 \\
Soybean meal (47\%pt.) & $13.6 \%$ & Ether extract (EE) & 4.63 \\
Soybean meal hulls & $9.5 \%$ & Crude fiber (CF) & 7.31 \\
Molasse & $1.5 \%$ & Ash & 7.01 \\
Vit.\& Min. premixture & $0.3 \%$ & NFE & 49.29 \\
Limestone & $2.4 \%$ & TDN & 70.25 \\
Sodium bicarbonate & $0.4 \%$ & & \\
Sodium chloride & $1 \%$ & & \\
Ammonium chloride & $0.5 \%$ & & \\
Sum & 100 & & \\
The TDN (total digestible nutrients) & $=$ the percentage of food that digested from \\
carbohydrate, proteins and fats & &
\end{tabular}

\subsection{Determination of digestibility coefficient of diet:}

Only a $10 \%$ of collected fecal matter (representative samples) was taken and were dried at $60^{\circ} \mathrm{C}$ for $48 \mathrm{hrs}$ to remove water content. DM content was determined, the dry samples were ground allowed to pass through $1 \mathrm{~mm}$. screen sieve and kept for analysis (Mousa et al., 2012).

Proximate chemical analysis of feed and feces samples for dry matter $(\mathrm{DM})$, crude protein $(\mathrm{CP})$, ether extract $(\mathrm{EE})$, crude fiber (CF), nitrogen free extract (NFE) and ash was done according to A.O.A.C. (1995).

Feed digestibility coefficient for feed stuff was determined as follow (McDonald et al, 2011):

Digestibility coefficient $=($ feed intake - feces weight $) \times 100$. Feed intake

2.3. Determination of expressions for selected bacterial DNA of Ruminococcus flavefaciens, Ruminococcus albus and Fibrobacter succinogenes genes by real-time PCR analysis.

Rumen liquor samples were collected after morning meal, using a suitable stomach tube connecting with a suction plastic syringe $250 \mathrm{ml}$ capacity (Grummer et al., 1993). About 100-200 ml of rumen fluid was collected in sterile, clean and dry Peaker. Samples of rumen fluid were taken 3 4 hours after feeding (Dolezal et al., 2005).

The rumen fluid samples were immediately collected and placed in $2 \mathrm{ml}$ Eppendorf tube and stored at $-80^{\circ} \mathrm{C}$ till RNA extraction by using Real Time polymerase chain reaction (RT-PCR) with 16S rRNA (Stevenson and Weimer, 2007). Forward and reverse primers sequence for Ruminococcus flavefaciens, Ruminococcus albus and Fibrobacter succinogenes genes were showed in table 2 .

\begin{tabular}{lll}
\multicolumn{3}{l}{ Table 2 Forward and reverse primer sequences used in qPCR. } \\
\hline & forward primer (5`------ $\left.3^{\star}\right)$ & reverse primer (5 ----- /3) \\
\hline $\begin{array}{l}\text { Ruminococcus } \\
\text { flavefaciens }\end{array}$ & GGACGATAATGACGGTACTT & GCAATC(CT)GAACTGGGACAAT \\
$\begin{array}{l}\text { Fibrobacter } \\
\text { succinogenes }\end{array}$ & GGTATGGGATGAGCTTG & GCCTGCCCCTGAACTATC \\
$\begin{array}{l}\text { Ruminococcus } \\
\text { albus }\end{array}$ & CCCTAAAAGCAGTCTTAGTTCG & CCTCCTTGCGGTTAGAACA \\
\hline
\end{tabular}

\subsection{Statistical analysis:}

All collected numerical data were tested statistically by using One-Way ANOVA at 5\% level of significance followed by Fishers Least Significant Difference test (LSD). Duncan multiple tests at $(p<0.05)$ (Duncan, 1959) were applied to evaluate the differences among means. The statistically homogenous means were denoted by similar alphabets. All analyses were performed using SPSS 16.0 version for Windows.

\section{RESULTS}

3.1. Digestibility coefficient of diet:

Table 3 showed that the dry matter digestibility (DM) percentages, crude protein digestibility $(\mathrm{CP})$ percentages, crude fiber (CF) digestibility and nitrogen free extract (NFE) significantly increased in both $S$. cerevisiae and chitozan groups when compared with the control group. Also, there was significant increase in Saccharomyces cerevisiae group when compared with chitozan group during all periods of treatment. The ether extract digestibility (EE) percentages increased significantly in $S$. cerevisiae groups and nonsignificantly in chitozan group when compared with the control group during all periods of treatment.

Ash percentages digestibility significantly increased in both $S$. cerevisiae and chitozan groups when compared with the control group. All periods of treatment except at $12^{\text {th }}$ week increased significantly (Table 3)

3.3. Expressions of Ruminococcus flavefaciens, Ruminococcus albus and Fibrobacter succinogenes bacterial DNA genes

Treatment with Saccharomyces and chitozan groups caused a significant $(\mathrm{P}<0.05)$ up regulation of $R$. flavefaciens, $R$. albus and $F$. succinogenes gene expression compared to the control, with the significant highest expression in Saccharomyces treated group than chitozan and control groups during all periods of treatment (Table 4). $R$. flavefaciens gene expression level at $4^{\text {th }}$ week was increased non-significantly in Saccharomyces treated group when compared with chitozan group. Also, the data revealed that there was a significant increase in the expression level of $R$. flavefaciens, $R$. albus and $F$. succinogenes genes in chitozan group than control group. 
Table 3 Effect of feeding of Saccharomyces cerevisiae and chitosan on digestibility coefficient $(\%)$ of diet $($ mean \pm SE, $n=12)$

\begin{tabular}{llllllllll}
\hline D.C & \multicolumn{5}{c}{ Control } & \multicolumn{5}{c}{ Saccharomyces } & \multicolumn{3}{c}{ Chitozan } \\
& $8^{\text {th }}$ week & $12^{\text {th }}$ week & $16^{\text {th }}$ week & $8^{\text {th }}$ week & $12^{\text {th }}$ week & $16^{\text {th }}$ week & $8^{\text {th }}$ week & $12^{\text {th }}$ week & $16^{\text {th }}$ week \\
\hline DM & $60.99 \pm 0.72^{\mathrm{c}}$ & $62.39 \pm 0.75^{\mathrm{c}}$ & $61.90 \pm 0.71^{\mathrm{c}}$ & $70.79 \pm 0.36^{\mathrm{a}}$ & $71.67 \pm 0.30^{\mathrm{a}}$ & $71.38 \pm 0.63^{\mathrm{a}}$ & $67.08 \pm 0.21^{\mathrm{b}}$ & $67.49 \pm 0.43^{\mathrm{b}}$ & $68.03 \pm 0.16^{\mathrm{b}}$ \\
CP & $58.68 \pm 0.42^{\mathrm{c}}$ & $59.38 \pm 0.36^{\mathrm{c}}$ & $59.23 \pm 0.30^{\mathrm{c}}$ & $66.70 \pm 0.27^{\mathrm{a}}$ & $67.96 \pm 0.33^{\mathrm{a}}$ & $66.76 \pm 0.48^{\mathrm{a}}$ & $63.61 \pm 0.49^{\mathrm{b}}$ & $64.36 \pm 0.82^{\mathrm{b}}$ & $65.01 \pm 0.54^{\mathrm{b}}$ \\
EE & $81.48 \pm 0.37^{\mathrm{b}}$ & $82.01 \pm 0.84^{\mathrm{b}}$ & $82.12 \pm 0.75^{\mathrm{b}}$ & $83.62 \pm 0.55^{\mathrm{a}}$ & $85.00 \pm 0.72^{\mathrm{a}}$ & $84.52 \pm 0.64^{\mathrm{a}}$ & $82.27 \pm 0.31^{\mathrm{ab}}$ & $83.83 \pm 0.66^{\mathrm{ab}}$ & $83.45 \pm 0.75^{\mathrm{ab}}$ \\
CF & $61.08 \pm 0.21^{\mathrm{c}}$ & $62.10 \pm 0.28^{\mathrm{c}}$ & $61.78 \pm 0.31^{\mathrm{c}}$ & $68.71 \pm 0.31^{\mathrm{a}}$ & $69.66 \pm 0.46^{\mathrm{a}}$ & $69.02 \pm 0.40^{\mathrm{a}}$ & $65.69 \pm 0.58^{\mathrm{b}}$ & $65.97 \pm 0.80^{\mathrm{b}}$ & $66.67 \pm 0.49^{\mathrm{b}}$ \\
NFE & $66.40 \pm 0.38^{\mathrm{c}}$ & $67.98 \pm 0.49^{\mathrm{c}}$ & $67.14 \pm 0.33^{\mathrm{c}}$ & $80.28 \pm 0.37^{\mathrm{a}}$ & $80.42 \pm 0.10^{\mathrm{a}}$ & $80.79 \pm 0.27^{\mathrm{a}}$ & $75.54 \pm 0.26^{\mathrm{b}}$ & $75.84 \pm 0.38^{\mathrm{b}}$ & $76.20 \pm 0.51^{\mathrm{b}}$ \\
Ash & $11.88 \pm 0.69^{\mathrm{b}}$ & $12.38 \pm 0.69^{\mathrm{c}}$ & $11.88 \pm 0.69^{\mathrm{b}}$ & $20.68 \pm 0.80^{\mathrm{a}}$ & $21.76 \pm 0.83^{\mathrm{a}}$ & $20.68 \pm 0.80^{\mathrm{a}}$ & $18.48 \pm 0.90^{\mathrm{a}}$ & $18.15 \pm 0.84^{\mathrm{b}}$ & $18.27 \pm 0.90^{\mathrm{a}}$ \\
\hline
\end{tabular}

Means with different letters in the same rows are significantly different $(\mathrm{p}<0.05)$.

\begin{tabular}{|c|c|c|c|c|c|c|c|c|c|}
\hline \multirow[t]{2}{*}{ Period } & \multicolumn{3}{|c|}{ Control } & \multicolumn{3}{|c|}{ Saccharomyces } & \multicolumn{3}{|c|}{ Chitozan } \\
\hline & R. flavefaciens & R. albus & F. succinogenes & R. flavefaciens & R. albus & $F$. succinogenes & R. flavefaciens & R. albus & F. succinogenes \\
\hline $8^{\text {th }}$ week & $1.00 \pm 0.05^{\mathrm{b}}$ & $1.00 \pm 0.04^{\mathrm{c}}$ & $1.00 \pm 0.04^{\mathrm{c}}$ & $3.71 \pm 0.13^{\text {a }}$ & $2.93 \pm 0.14^{\mathrm{a}}$ & $3.61 \pm 0.15^{\mathrm{a}}$ & $3.30 \pm 0.11^{\text {a }}$ & $2.10 \pm 0.11^{\mathrm{b}}$ & $2.66 \pm 0.10^{\mathrm{b}}$ \\
\hline $10^{\text {th }}$ week & $1.00 \pm 0.05^{\mathrm{c}}$ & $1.00 \pm 0.08^{\mathrm{c}}$ & $1.00 \pm 0.08^{c}$ & $3.26 \pm 0.15^{\mathrm{a}}$ & $11.50 \pm 0.37^{\mathrm{a}}$ & $8.02 \pm 0.27^{\mathrm{a}}$ & $2.21 \pm 0.1^{\mathrm{b}}$ & $9.27 \pm 0.26^{\mathrm{b}}$ & $2.59 \pm 0.14^{\mathrm{b}}$ \\
\hline $12^{\text {th }}$ week & $1.00 \pm 0.06^{\mathrm{c}}$ & $1.00 \pm 0.08^{\mathrm{c}}$ & $1.00 \pm 0.05^{\mathrm{c}}$ & $4.48 \pm 0.14^{\mathrm{a}}$ & $12.32 \pm 0.46^{\mathrm{a}}$ & $8.90 \pm 0.25^{\mathrm{a}}$ & $2.38 \pm 0.11^{\mathrm{b}}$ & $4.83 \pm 0.30^{\mathrm{b}}$ & $4.18 \pm 0.20^{\mathrm{b}}$ \\
\hline $14^{\text {th }}$ week & $1.00 \pm 0.07^{\mathrm{c}}$ & $1.00 \pm 0.04^{\mathrm{c}}$ & $1.00 \pm 0.07^{\mathrm{c}}$ & $4.51 \pm 0.18^{\mathrm{a}}$ & $5.04 \pm 0.25^{\mathrm{a}}$ & $10.58 \pm 0.32^{\mathrm{a}}$ & $2.16 \pm 0.13^{\mathrm{b}}$ & $2.59 \pm 0.12^{\mathrm{b}}$ & $8.30 \pm 0.25^{\mathrm{b}}$ \\
\hline $16^{\text {th }}$ week & $1.00 \pm 0.07^{\mathrm{c}}$ & $1.00 \pm 0.06^{\mathrm{c}}$ & $1.00 \pm 0.05^{\mathrm{c}}$ & $8.48 \pm 0.18^{\mathrm{a}}$ & $3.54 \pm 0.21^{\mathrm{a}}$ & $4.24 \pm 0.21^{\mathrm{a}}$ & $3.54 \pm 0.13^{\mathrm{b}}$ & $3.37 \pm 0.18^{\mathrm{b}}$ & $2.70 \pm 0.13^{\mathrm{b}}$ \\
\hline
\end{tabular}

Means with different letters in the same rows are significantly different $(\mathrm{p}<0.05)$.

\section{DISCUSSION}

Concerning to the digestibility coefficient of diet, the obtained results revealed that Saccharomyces cerevisiae group had significantly higher in nutrient digestibility of dry matter (DM), crude protein (CP), ether extract (EE), crude fiber (CF), nitrogen free extract (NFE) and Ash than the control group. These results are in consistent with those obtained by Helal et al. (2010) in lactating Rahmani ewe who found significant increase in nutrient digestibility of dry matter (DM), crude protein (CP), ether extract, crude fiber $(\mathrm{CF})$, nitrogen free extract (NFE) and Ash in yeast containing Saccharomyces cerevisiae groups compared with the control group and Ghazanfar et al. (2015) in small dairy breeds heifers who found significant increase in nutrient digestibility of dry matter and crude protein in Saccharomyces cerevisiae groups compared with the control group. These results are in partially agreement with the results obtained by Bhanderi et al. (2016) in cows who recorded significant increase in digestibility of $\mathrm{DM}, \mathrm{CP}$ and $\mathrm{CF}$ and non-significant increase in EE and NFE in a yeast containing Saccharomyces cerevisiae groups compared with the control group. Also, these results are partially agreed with those obtained by Mousa et al. (2012), who found significant increase in digestibility of DM, CP and CF in a yeast containing Saccharomyces cerevisiae groups while EE digestibility increased non significantly in a yeast containing Saccharomyces cerevisiae groups compared with the control group in male lambs. Moreover, these results are partially agreed with those obtained by Reséndiz-Hernández et al. (2012) in lambs who recorded significant increase in nutrient digestibility of dry matter and non-significant increase in crude protein in yeast containing Saccharomyces cerevisiae groups compared with the control group.

On the contrary, GarcôÂa et al. (2000) in sheep reported non-significant change in digestibility of DM in a yeast culture containing Saccharomyces cerevisiae group compared with the control group. On the same respect, Ding et al. (2008) in lambs revealed no significant increase in nutrient digestibility of dry matter and crude protein and starch (NFE) in Saccharomyces cerevisiae group compared with the control group. Also, Kowalik et al. (2016) in rams found non-significant decrease in nutrient digestibility of crude protein, crude fiber and $\mathrm{N}$-free extract in yeast containing Saccharomyces cerevisiae groups compared with the control group. These results may be attributed to different animal species of the studies or the differences in the level of addition of SC used or different strains of SC used (Newbold, et. al., 1995) or nature and quality of diet fed to animals (Desnoyers et al., 2009) as variation may be due to the variation in animal species (Ding et al., 2008; GarcõÂa et al., 2000; Mousa et al., 2012; ReséndizHernández et al., 2012) for lambs or may be due to the variation different strains of SC used Saccharomyces cerevisiae (Levucell) (Bhanderi et al., 2016; Kowalik et al., 2016) or may be due to the nature and quality of diet fed to animals (Kowalik et al., 2016).

The increase in crude protein (CP) digestibility in Saccharomyces cerevisiae group due to stimulation of proteolytic rumen bacteria (Williams et al., 1991) and the increase in crude fiber $(\mathrm{CF})$ digestibility due to increased cellulose degrading microbial biomass population inside rumen so improve crude protein $(\mathrm{CP})$ and crude fiber $(\mathrm{CF})$ digestibility which affected by yeast supplementation (Ghazanfar et al., 2015). The increased digestibility can be due to stable rumen $\mathrm{pH}$ and removal of oxygen from the rumen in the yeast supplemented group. That stable rumen $\mathrm{pH}$ provides better environment for growth of rumen microbes, especially cellulose degrading bacteria and fungi. At the same time the anaerobic condition inside rumen also helped in better growth of fibrolytic microbial biomass helps increase fiber digestibility (Bhanderi et al., 2016). Consequently, these microbial species helped in better fiber digestion. The stable $\mathrm{pH}$ also enhanced microbial protein synthesis in the rumen (Lascano et al., 2012).

The results of the present study revealed that the feeding of chitozan showed significantly higher nutrient digestibility of dry matter $(\mathrm{DM})$, crude protein $(\mathrm{CP})$, crude fiber $(\mathrm{CF})$, nitrogen free extract (NFE) and ash than the control group except in EE showed non-significant increase in chitozan group comparing with the control group. These results were nearly similar to the results of Araújo et al. (2015) in steers, Mingoti et al. (2016) in dairy cows, Dias et al. (2017) in 
steers and Del Vallea et al. (2017) in Holstein dairy cows who reported that supplying chitozan significantly increased the digestibility of dry matter (DM), crude protein (CP) and did not show any significant change in EE digestibility. Also, these results are partially in agreement with those obtained by Henry et al. (2015) in beef heifers who recorded significant increase in nutrient digestibility of dry matter in chitozan group compared with the control group but no significant differences for digestibility of $\mathrm{CP}$ in chitozan group compared with the control group. Moreover, these results are partially agreed with those obtained by Goiri et al. (2014) in sheep, who showed non-significant decrease in nutrient digestibility of $\mathrm{CP}$ and $\mathrm{EE}$ in chitozan group as compared to the control. Also, Gandra et al. (2016) in beef heifers showed significant increase in nutrient digestibility of DM but non-significant increase in $\mathrm{CP}$ and $\mathrm{EE}$ in chitozan group compared with the control group. Moreover, the obtained results of the present study are partially agreed with those obtained by Vendramini et al. (2016) in Holstein cows who found non-significant changes in DM and $\mathrm{CP}$ and $\mathrm{EE}$ in chitozan $(\mathrm{CH})$ comparing with the control. On the contrary, Wencelova et al. (2014) in sheep reported significant decrease in digestibility of DM in chitozan group compared with the control group. These results may be attributed to different animal species of the studies or the dosage of chitozan used or nature and quality of diet fed to animals (Vendramini et al., 2016) as variation may be due to the variation in animal species (Goiri et al., (2014), Gandra et al. (2016) and Vendramini et al. (2016) in lambs, beef heifers and Holstein cows, respectively) or variation may due to the level of dose of chitozan used 0.5 and $1 \%$ of dietary (Henry et al., 2015).

The significant increase of nutrient digestibility of dry matter, nitrogen free extract (NFE), crude fiber, crude protein and ash in chitozan group than control group can be attributed to that $\mathrm{CHI}$ action on ruminal bacteria responsible for proteolysis and deamination since $\mathrm{CHI}$ have also indicated by increased ruminal ammonia nitrogen in this study.

The significant increase of nutrient digestibility of crude fiber in chitozan group than control group could be attributed to that CHI stimulate growth and activity of cellulolytic bacteria because antimicrobial activity of chitozan help in better growth of fibrolytic microbial biomass helps increase fiber digestibility indicated by significant up regulation of Ruminococcus albus, Ruminococcus flavefaciens and Fibrobacter succinogenes genes expression level in chitozan treated group when compared with the control during all periods of treatment in this study.

The chitozan mechanism of action is still not clear, but ionic interactions between positively charged surface chitozan amino groups and negatively charged in the surface of bacteria, resulting in alteration of membrane permeability, has been the most acceptable theory (Helander et al., 2001; Kong et al., 2010). Zhong et al. (2008) reported that Grampositive bacteria are more susceptible to derivatives of $\mathrm{CHI}$ as a con- sequence of the Gram-negative outer membrane barrier. The in- crease in protein digestibility could be related to the action of $\mathrm{CHI}$ on bacteria which promote proteolysis and deamination, resulting in a decrease of ruminal protein degradation and increasing amino acids availability in the intestine, a similar effect of ionophores (Yang and Russell, 1993). Thus, we suggest that the increase of the nutrient digestibility with $\mathrm{CHI}$ addition is due to its capacity to change rumen microorganisms and digestive processes, acting mainly on the gram-negative bacteria, which are justified by improvement in NDF and $\mathrm{CP}$ digestibility. Also, the non-significant change in EE could be interacting with negatively charged free FA, thereby preventing the biohydrogenation process, and/or could be affecting certain microbial population's growth. Another reason which may explain the absence of CHI effects on FA biohydrogenation in the current study is the level of $\mathrm{EE}$ in the diet (Mingoti et al., 2016).

Regarding the expressions of bacterial Ruminococcus flavefaciens, Ruminococcus albus and Fibrobacter succinogenes genes, the obtained results from the present study revealed a significant $(\mathrm{P}<0.05)$ up regulation of Ruminococcus flavefaciens, Ruminococcus albus and Fibrobacter succinogenes genes expression level in yeast containing saccharomyces cerevisiae in ruminal fluid following administration of Saccharomyces cerevisiae treated group when compared with the control during all periods of treatment. These results are in consistence with the findings obtained by Jiang et al. (2017) in lactating dairy cows and Ogunade et al. (2019) in steers, who revealed that addition of SC significantly increased the gene expression of cellulolytic bacteria in yeast containing Saccharomyces cerevisiae group compared with the control group. On the same respect, Chaucheyras and Fonty (2001 and 2002) in lambs and Bhanderi et al. (2016) in Kankrej cows revealed that addition of SC significantly increased the cellulolytic bacteria number in yeast containing Saccharomyces cerevisiae group compared with the control group. These results are partially in agreement with obtained by Vyas et al. (2014) in beef heifers who recorded significant increase in Ruminococcus flavefaciens gene expression and nonsignificant changes in F. succinogenes gene expression in yeast containing Saccharomyces cerevisiae group compared with the control group

The higher expression level of Ruminococcus flavefaciens, Ruminococcus albus and Fibrobacter succinogenes genes following administration of Saccharomyces cerevisiae treated group than non-treated control may attributed to yeast supplements increase dry matter degradation rates and thereby improve the release of energy that can be used for microbial growth (Chaucheyras and Fonty, 2002; Kamel et al., 2004) indicated by decrease of ruminal ammonia nitrogen because numerous bacterial species, particularly cellulolytic bacteria, use ammonia as a preferential source of nitrogen (Chaucheyras and Fonty, 2002). Also, Live S. cerevisiae strains are capable of oxygen scavenging in vitro and in vivo (Newbold et al., 1995; Chaucheyras et al., 1996). A lower redox potential would provide better conditions for growth and metabolism of anaerobic microorganisms, especially for extremely oxygen sensitive species such as cellulolytic organisms because cellulolytic species are known to be extremely oxygen-sensitive and indeed oxygen acts as a toxic substance (Hungate, 1996). About 10-20 1 of oxygen are considered to enter the rumen of adult animals within a day, particularly during the meals, and up to $3 \mathrm{mM}$ of dissolved $\mathrm{O} 2$ are measured in ruminal fluid (Ellis et al., 1989). Moreover, nutrients supply (vitamins, amino acids, peptides) by the yeast could stimulate growth of certain microorganisms at the beginning of rumen colonization. Yeasts are also reported to release vitamins and other growth factors (organic acids, B-vitamins and amino acids) that are 
essential for the growth of cellulolytic bacteria (Chiquette, 2009).

Regarding to the effect of feeding of chitozan on gene expression of cellulolytic bacteria selected bacterial DNA of Ruminococcus flavefaciens, Ruminococcus albus and Fibrobacter succinogenes genes, the present study revealed a significant up regulation of Ruminococcus flavefaciens, Ruminococcus albus and Fibrobacter succinogenes gene expression level in chitozan group when compared with the control during all periods of treatment. These results are in not agreement with the results of Belanche et al. (2016) who reported that supplying chitozan (CHI) on in in-vitro rumen digestion and fermentation as artificial rumen system of Holstein-Frisian cows caused negative impact on the abundance of most of the rumen cellulolytic bacteria. These results may be attributed to different animal species of the studies or related to the diet composition (forage to concentrate ratio), the dosage, and the method of supply (in vitro supply) (vendramini et al., 2016). But in this study, there was significant up regulation of cellulolytic bacteria with significant increase in $\mathrm{CF}$ digestibility in chitozan group when compared with the control during all periods of treatment so need further investigation because the literatures cited in effect limited due to recent application of chitozan in ruminant as antimicrobial feed additive.

The significant increase in bacterial community different species suggested that these chitooligosaccharides can further be used by some gut bacteria as carbon source (Chen et al., 2002) and could explain to some extent the change in the bacterial community Thus, we suggest that the increase of the nutrient digestibility with CHI addition due its capacity to change rumen microorganisms and digestive processes, acting mainly on the Gram-positive bacteria, that is justified by improvement in NDF and CP digestibility (Mingoti et al., 2016).

\section{REFERENCES}

1. Araújo, A. P. C.; Venturellia, B. C.; Santosa, M.C.B.; Gardinala R.; Cônsoloa, N. R. B.; Calomenia, G. D.; Freitas, J. E.; R.V.; Gandraa J. R.; Paiva, P. G. and Rennóa, F. P. (2015): Chitosan affects total nutrient digestion and ruminal fermentation in Nellore steers. Anim. Feed Sci. Technol. 206: 114-118

2. Belanche, A.; Pinloche, E.; Preskett, D. and Newbold, C. J. (2016): Effects and mode of action of chitosan and ivy fruit saponins on the microbiome, fermentation and methanogenesis in the rumen simulation technique. FEMS Microbiology Ecology. 92 (1): 1-13

3. Bhanderi, B. M.; Parnerkar, S.; Aggarwal, A.; Shankhpal, S.; Thube, H. and Pathan, S. (2016): effect of supplementing of two different commercial strains of yeast cultures on rumen fermentation, nutrient digestibility and biochemical profile in Kankrej cows. Int. J. Adv. Res. 4(8): 756-772.

4. Chaucheyras, F. and Fonty G., (2001): Establishment of cellulolytic bacteria and development of fermentative activities in the rumen of gnotobiotically-reared lambs receiving the microbial additive Saccharomyces cerevisiae CNCM I-1077. Reprod. Nutr. Dev. 41: 57-68.

5. Chaucheyras, F. and Fonty, G. (2002): Influence of a probiotic yeast (Saccharomyces cerevisiae CNCM I-1077) on microbial colonization and fermentations in the rumen of newborn lambs. Microb. Ecol. Health Dis. 14: 30-36.

6. Chaucheyras, F; Fonty G; Bertin G and Gouet P. (1995): Effects of live Saccharomyces cerevisiae cells on zoospore germination, growth, and cellulolytic activity on the rumen anaerobic fungus Neocallimastix frontalis. Curr. Microbiol. 31: $201-205$.

7. Chen, H. C.; Chang, C. C. and Mau, W. J. (2002): Evaluation of $\mathrm{N}$-acetylchitooligosaccharides as the main carbon sources for the growth of intestinal bacteria. Fems. Microbiol. Lett. 209: 53-56.

8. Chevaux, E. and Fabre, M. M. (2007): Probiotic yeast in small ruminants. Feed Mix, 15 (1) 28029.

9. Chiquette, J. (2009): The role of probiotics in promoting dairy production. WCDS Adv. Dairy Technol. 21: 143-157.

10. Del Vallea, T. A.; De Paiva, P. G. ; De Jesusb, E. F. ;De Almeidaa. G. F.; Zanferaria, F.; Costaa, A. G. B. V. B.; Buenoc, I. C. S. and Rennóa, F. P. (2017): Dietary chitosan improves nitrogen use and feed conversion in diets for mid lactation dairy cows. Livestock Sci. 201:22-29.

11. Desnoyers, M., Giger-Reverdin, S., Bertin, G., DuvauxPonter, C. and Sauvant, D. (2009): Meta-analysis of the influence of Saccharomyces cerevisiae supplementation on ruminal parameters and milk production of ruminants. J. of Dairy Sci. 92:1620-1632.

12. Ding, J.; Zhou, Z. M.; Ren, L. P. and Q. X. Meng (2008): Effect of Monensin and live yeast supplementation on growth performance, nutrient digestibility, carcass characteristics and ruminal fermentation parameters in lambs fed steam-flaked corn-based diets. Asian-Aust. J. Anim. Sci. 21 (4): 547 - 554.

13. Dolezal, P. ; Dolezal, J. and Trinacty, J. (2005): The effect of Saccharomyces cerevisiae on ruminal fermentation in dairy cows. Czech J. Anim. Sci. 50 (11): 503-510

14. Duguma, G.; Mirkena, T.; Haile, A.; Iñiguez, L. and Okeyo, A. M., (2011): Identification of smallholder farmers and pastoralists' preferences for sheep breeding traits: choice model approach. Animal 5: 1984-1992.

15. Duncan, R. G. (1959): Multiple range and multiple F tests. Biometrics. 11: 1-42

16. Ellis, J. A.; Williams, A. G. and Lloyd, D. (1989): Oxygen consumption by ruminal microorganisms: protozoal and bacterial contributions. Appl. Env. Microbiol. 55 (10): 2583 2587.

17. Gandra, J. R.; Takiya, C. S.; de Oliveira, E. R.; de Paiva, P. G.; de Goes, R. H. de T. B.; Gandra, É. R. de S. and Araki, H. M. C. (2016): Nutrient digestion, microbial protein synthesis, and blood metabolites of Jersey heifers fed chitosan and whole raw soybeans R. Bras. Zootec. 45 (3):130-137.

18. Garcõ̂̂A, C.C.G.; Mendoza, M.G.D.; GonzaÂlez, M. S.; Cobos, P. M.; Ortega C. M. E. and Ramirez L. R. (2000): Effect of a yeast culture (Saccharomyces cerevisiae) and monensin on ruminal fermentation and digestion in sheep. Anim. Feed Sci. and Technol. 83: 165-170

19. Ghazanfar, S; Anjum, M. I.; Azim, A. and Ahmed, I. (2015): Effect of dietary supplementation of Yeast (Saccharomyces cerevisiae). Culture and growth performance, blood parameters, nutrient digestability and fecal flora of dairy heifers. J. of Anim. \& Plant Sci. 25 (1): 53-59.

20. Goiri, I.; Oregui, L. M. and Garcia-Rodriguez, A. (2014): Dose-response effects of chitosans on in vitro rumen digestion and fermentation of mixtures differing in forage-toconcentrate ratios. Anim. Feed Sci. Technol. 151: 215-227

21. Grummer, R. R.; Melissa, L. L. and Barmore, J. A. (1993) Rumen fermentation and lactation performance of cows fed roasted soybeans and tallow, J. Dairy Sci. 76: 2674-2681.

22. Helal, F. I. S. and Abdel-Rahman, K. A. (2010): Productive performance of lactating ewes diet supplementing with dry yeast and/or bentonite as feed additives. World J. Agric. Sci. 6 (5): 489-498

23. Helander, I. M.; Nurmiaho-Lassila, E. L.; Ahvenainen, R.; Rhoades, J. and Roller, S. (2001): Chitosan disrupts the barrier properties of the outer membrane of Gram-negative bacteria. Int. J. Food Microbiol. 71: 235-244.

24. Henry, D. D.; Ruiz-Moreno, M.; Ciriaco, F. M.; Kohmann, M.; Mercadante, V. R. G.; Lamb, G. C. and DiLorenzo, N. (2015): Effects of chitosan on nutrient digestibility, methane 
emissions, and in vitro fermentation in beef cattle. J. Anim. Sci., 93(7): 3539-3550.

25. Hungate, R.E. (1966): The rumen and its microbes, Academic Press, New York and London.

26. Jacob, M. E. and Nagaraja, T. G. (2012): Use of direct-fed microbials as a preharvest food safety intervention in cattle. In: Direct-Fed Microbials and Probiotics for Animals: Science and Mechanisms of Action. T. R. Callaway and S. C. Ricke (eds.) Springer Publ., NY. Pp 189-202.

27. Jiang, Y.; Ogunade, I. M.; Qi, S.; Hackmann, T. J.; Staples, C.R. and Adesogan, A. T. (2017): Effects of the dose and viability of Saccharomyces cerevisiae. 1. Diversity of ruminal microbes as analyzed by Illumina MiSeq sequencing and quantitative PCR. J. Dairy Sci. 100, 325-342.

28. Jouany, J. P.; Mathieu, F.; Sénaud, J.; Bohatier, J.; Bertin, G. and Mercier, M. (1999): Influence of protozoa and fungal additives on ruminal $\mathrm{pH}$ and redox potential. South African J. of Anim. Sci. 29: 65-66.

29. Kamel, H. E. M.; Sekine, J.; El Waziry, A. M. and Yacount, M. H. M. (2004): Effects of Saccharomyces cerevisiae on the synchronization of organic matter and nitrogen degradation kinetics and microbial nitrogen synthesis in sheep fed Barseem hay (Trifolium alexandrinum). Small Rumin. Res. 52: 211216.

30. Kong, M.; Chen, X. G.; Xing K and Park, H. J. (2010): Antimicrobial properties of chitozan and mode of action: a state of the art review. Int. J. Food Microbiol. 144: 51-63.

31. Kowalik, B.; Jacek, S.; Renata, M. and Majewska, M. (2016): The effect of live Saccharomyces cerevisiae yeast in the diet of rams on the digestibility of nutrients, nitrogen and mineral retention, and blood serum biochemical parameters. Turk. J. Vet. Anim. Sci. 40: 534-539

32. Lascano, G. J.; Heinrichs A. J. and Tricarico J. M. (2012): Substitution of starch by soluble fiber and Saccharomyces cerevisiae dose response on nutrient digestion and blood metabolites for precision-fed dairy heifers. J. Dairy Sci. 95 (6): 3298-3309.

33. Li, H. Y.; Yan, S. M.; Shi, B. L. and Guo, X. Y. (2009): Effect of Chitosan on Nitric Oxide Content and Inducible Nitric Oxide Synthase Activity in Serum and Expression of Inducible Nitric Oxide Synthase mRNA in Small Intestine of Broiler Chickens. Asian-Aust. J. Anim. Sci. 22: 1048-1053.

34. Matsuhashi, S. and Kume, T. (1997): Enhancement of antimicrobial activity of chitosan by irradiation. J. Sci. Food Agric. 73: 237-241

35. McDonald, P.; Greenhalalgh, J. F. D.; Morgan, C. A.; Edwards, R. A.; Sinclair, L. and Wilkinson, R. (2011): Animal Nutrition ( $7^{\text {th }}$ ed.). USA: Longman Scientific and Technical.

36. Mingoti, R. D. ;FreitasJr, J. E.; Gandra, J. R. ; Gardinal, R.; Calomeni, G. D. ; Barletta, R. V. ; Vendramini, T. H. A. ; Paiva, P. G. and Rennó, F. P. (2016): Dose response of chitosan on nutrient digestibility, blood metabolites and lactation performance in Holstein dairy cows. LivestockScience.187: 35-39.

37. Mousa, K. h. M. El-Malky, O. M. Komonna, O. F. and Rashwan, S. E. (2012): Effect of some yeast and minerals on the productive and reproductive performance in ruminants. J. of American Sci. 8(2): 291-303.

38. Newbold, C. J.; Wallace R. J.; Chen, X. B. and McIntosh, F. M. (1995): Different strains of Saccharomyces cerevisiae differ in their effects on ruminal bacterial numbers in vitro and in sheep. J. Anim. 73: 1811-1818.

39. Ogunade, I.; Schweickart, H.; McCoun, M.; Cannon, K. and McManus, C. (2019): Integrating 16S rRNA Sequencing and LC-MS-Based Metabolomics to Evaluate the Effects of Live Yeast on Rumen Function in Beef Cattle. Animals. 9, 1, 1-14

40. Polizel, D. M.; Mezzena, L. G.; Souza, G. R. A. de; Gentil, R. S.; Ferreira, E. M. and Alves, A. P.; Susin, F. I. (2016) Performance and carcass traits of goat kids fed highconcentrate diets containing citrus pulp or soybean hulls. Ciência Rural, Santa Maria. 46 (4): 707-712.

41. Reséndiz-Hernández, M.; Bárcena-Gama, J. R.; CrosbyGalván, M. M.; Cobos-Peralta, M.; Herrera-Haro, J.; Hernández-García, P. A. and Carreón-Luna, L. (2012): Effect of organic selenium and chromium and saccharomyces cerevisiae. Publicado Como ARTÍCULO en Agrociencia. 46 (8): 745-755

42. Roger, V.; Fonty, G.; Komisarczuk-Bony, S. and Gouet, P. (1990): Effects of physicochemical factors on the adhesion to cellulose Avicel of the ruminal bacteria Ruminococcus flavefaciens and Fibrobacter succinogenes subsp. succinogenes. Appl. Environ. Microbiol. 56: 3081-3087.

43. Stevenson, D. M., and Weimer, P. J. (2007): Dominance of Prevotella and low abundance of classical ruminal bacterial species in the bovine rumen revealed by relative quantification real-time PCR. Appl. Microbiol. Biotechnol. 75: 165-174.

44. Vendraminia, T .H .A.; Takiyaa, C. S.; Silvaa, T. H.; Zanferaria F.; Rentasa, M. F.; Bertonia, J. C.; Consentinia, C. E. C.; Gardinala R.; Acedob, T. S. and Rennóa, F. P. (2016): Effects of a blend of essential oils, chitosan or monensin on nutrient intake and digestibility of lactating dairy cows. Anim. Feed Sci. and Technol. 214: 12-21.

45. Vyas, D.; Uwizeye, A.; Mohammed, R.; Yang, W. Z.; Walker, N. D. and Beauchemin, K. A. (2014): The effects of active dried and killed dried yeast on subacute ruminal acidosis, ruminal fermentation, and nutrient digestibility in beef heifers. J. Anim. Sci. 92: 724-732

46. Williams, P. E. V.; Tait, C. A. G.; Innes, G. M. and Newbold, J. M. (1991): Effects of inclusion of yeast culture (Saccharomyces cervisiae plus growth medium) in the diet of dairy cows on milk yield and forage degradation and fermentation patterns in the rumen of steers. J. Anim. Sci. 69: 3016-3026.

47. Yang, C.M. and Russell, J.B. (1993): The effect of monensin supplementation on ruminal ammonia accumulation in vivo and the numbers of amino acid-fermenting bacteria. J. Anim. Sci. 71: 3470-3476.

48. Zhong, Z. M.; Xing, R.G.; Liu, S.; Wang, L; Cai, S. B. and Li, P. C. (2008): Synthesis of acyl thiourea derivatives of chitosan and their antimicrobial activities in vitro Carbohydr. Res. 343: 566-570. 